\title{
Gambel Oak Control Studies in Southwestern Colorado
}

\section{ROBERT W. MARQUISS}

Highlight: Gambel oak (Quercus gambelii) was treated with several brush-killing herbicides in southwestern Colorado. Tordon, alone or in a mixture, as a foliar spray increased the percentage of dead stems and reduced the occurrence of root sprouts when compared to other herbicides tested. One-half pound of Tordon $22 \mathrm{~K}$ mixed with 2,4,5-TP at the 11/2 and 2-pound rates (ae/acre) and Tordon $22 \mathrm{~K}$ at the 2-pound rate have resulted in the best herbicide treatments for controlling Gambel oak in southwestern Colorado.

Gambel oak (Quercus gambelii) is a major component of several million acres of rangeland in Colorado, Arizona, Nevada, New Mexico, and Utah (Brown, 1958). Gambel oak is tolerant to a variety of climatic and soil conditions. This browse species is found throughout the ponderosa pine zone. It extends into the aspen and spruce-fir zones at the higher elevations, and into pinyon pine and juniper types at lower elevations (Brown, 1958; Christensen, 1949; and Price, 1938).

Dense stands of oak on rangelands

The author was assistant professor of range science, Colorado State University, stationed at the San Juan Basin Branch Station, Hesperus, Colorado. He is at present assistant professor of biology at Fort Lewis College, Durango, Colo.

The paper is published with the approval of the director of the Colorado State University Experiment Station as Scientific Series Paper No. 1650.

Manuscript received May 29, 1971. present many management problems. Livestock tend to overgraze open parks and graze only lightly under the brush (Jefferies and Norris, 1965). Many methods of controlling Gambel oak have been tried but the results generally have been disappointing. A few treatments have provided rather successful control of oak but they have not been consistent (Marquiss and Norris, 1968; Heikes, 1964; Pearl, 1965; and Johnson et. al., 1969).

\section{Tests Made}

During a 7-year period from 1962 to 1969 in the San Juan Basin of southwestern Colorado, many tests to control Gambel oak were attempted. These studies included four herbicides $(2,4,5-\mathrm{T}$ amine, 2,4,5-T ester, 2,4,5-DP, and $2,4,5$-TP), applied at three initial rates (1-, 2- and, 3-lb. ae/acre) with repeated treatments during successive years. Three dates of application (mid-June, early July and mid-July) were tested. In other trials liquid Tordon $22 \mathrm{~K}$ and Tordon mixtures 212 and 225 were compared to mixtures of Tordon 22K-2,4,5-TP, and with Tordon beads, Tordon pellets and Fenuron pellets. Tordon 212 is a mixture of $1-1 b$. of Tordon $22 \mathrm{~K}$ and $2-\mathrm{lb}$. of 2,4-D per gallon and Tordon 225 is a mixture of 1-lb. Tordon $22 \mathrm{~K}$ and $1 \mathrm{lb}$. of 2,4,5-T per gallon.

\section{Results}

Climatic variation no doubt played an important role in the effectiveness of the herbicides, since results with the same herbicide treatment applied over a period of years gave highly variable results from year to year.

All treatments produced partial kill of mature stems and a substantial reduction in canopy cover. Three successive years of treatment produced a substantial increase in percentage defoliation and percentage of dead mature stems over a single initial treatment or even two successive years of treatment. From 15 to $47 \%$ of the mature stems were killed by the 2,4,5-TP, 2,4,5-DP, and 2,4,5-T ester when treated 3 consecutive years. Mature stems killed 
by the Tordon herbicides ranged from 13 to $80 \%$. Sprouting was abundant even when the brush had been treated for three successive years with 2,4,5-TP and 2,4,5-DP and 2,4,5-T; but sprouting from the more effective Tordon treatments was sparse.

Of the non-Tordon herbicides, the best oak control was obtained with 2,4,5-TP and 2,4-DP at the 2-lb. and 3-lb. rates; but even at these rates only about $47 \%$ of the mature stems were killed. Defoliation was variable with a maximum of $75 \%$ of the foliage removed after two repeated applications. In all cases root sprouting was abundant on all plots two years after final treatment. The results with 2,4,5-T amine were poorer than 2,4,5-TP or 2,4,5-DP esters. Phenoxy type herbicides, when applied for 1,2 , or 3 successive years, killed an increasing percentage of dead mature stems. However, the total number of live stems coming from sprouts following treatment offset much of the initial beneficial effects of treatment. As would be expected, the repeated $1-1 \mathrm{~b}$. rate of the various herbicides did not defoliate the oak or open the oak thickets as well as the repeated 2- or 3-1b. rates.

Grass production was more abundant and more vigorous on the treated plots than on the non-treated plots. Opening up the stand of oak, even with stem kills of only $47 \%$, increased the forage production by about $100 \%$.

A high degree of oak control was generally obtained when Tordon was included in the herbicide treatment. One half pound of Tordon $22 \mathrm{~K}$ mixed with $2,4,5-\mathrm{TP}$ at $1 \frac{1 / 2}{2}$ or $2-1 \mathrm{~b}$./acre rates was effective in controlling Gambel oak. These treatments killed as much as $80 \%$ of the mature stems and caused a $100 \%$ defoliation. Tordon $22 \mathrm{~K}$ alone at the $2-1 b$. rate was the only treatment as effective as the Tordon-2,4,5-TP mixture. These treatments controlled mature stems better and kept sprouting after treatment at a minimum compared to other herbicide treatments. Tordon mixtures 212 and 225 were effective, but to a lesser degree than the Tordon-2,4,5-TP mixture. The Tordon beads and pellets and the Fenuron pellets were not effective in controlling mature oak even at the rates up to $2 \frac{1}{2} \mathrm{lb}$./acre.

In general, the higher the rate of herbicide, the greater the kill and control of oakbrush. All dates of application during spring and summer produced about the same results.

\section{Literature Cited}

Brown, Harry E. 1958. Gambel oak in the west central Colorado. Ecology 39:317-327.

Christensen, Earl M. 1949. The ecology and geographic distribution of oakbrush (Quercus gambellii) in Utah. M.S. thesis, Salt Lake City, Utah. Univ. of Utah Lib. 70 p.

Heikes, E. G. 1964. Tordon and other herbicides field testing for the control of deep rooted perennial weeds in Colorado. Down to Earth 2(3):9-12.

Jefferies, N. W., and J. J. Norris. 1965. Management and improvement of Gambel Oak ranges. Colorado Agr. Exp. Sta. PR 147.

Johnson, Thomas N., Jr., W. P. Clary, and P. F. Ffolliott. 1969. Gambel oak control on the Beaver Creek Pilot Watershed in Arizona. Agr. Res. Serv., U.S. Dep. Agr. Crops Res. Div. 34-104. 8 p.

Marquiss, R. W., and J. J. Norris. 1968. Management and improvement of oakbrush ranges. Colorado State Univ. PR 68-7.

Pearl, R. W. 1965. Gambel oak control in New Mexico. West Weed Control Conf. Res. PR p 40.

Price, Raymond. 1938. Artificial reseeding on oakbrush range in central Utah. U.S. Dep. Agr. Cir. 458. 